\title{
Causes of labour supply and demand mismatches in the Dutch building trades
}

Citation for published version (APA):

de Grip, A. (1987). Causes of labour supply and demand mismatches in the Dutch building trades. De Economist, 135(2), 182-200. https://doi.org/10.1007/BF01718261

Document status and date:

Published: 01/01/1987

DOI:

10.1007/BF01718261

Document Version:

Publisher's PDF, also known as Version of record

\section{Please check the document version of this publication:}

- A submitted manuscript is the version of the article upon submission and before peer-review. There can be important differences between the submitted version and the official published version of record.

People interested in the research are advised to contact the author for the final version of the publication, or visit the DOI to the publisher's website.

- The final author version and the galley proof are versions of the publication after peer review.

- The final published version features the final layout of the paper including the volume, issue and page numbers.

Link to publication

\footnotetext{
General rights rights.

- You may freely distribute the URL identifying the publication in the public portal. please follow below link for the End User Agreement:

www.umlib.nl/taverne-license

Take down policy

If you believe that this document breaches copyright please contact us at:

repository@maastrichtuniversity.nl

providing details and we will investigate your claim.
}

Copyright and moral rights for the publications made accessible in the public portal are retained by the authors and/or other copyright owners and it is a condition of accessing publications that users recognise and abide by the legal requirements associated with these

- Users may download and print one copy of any publication from the public portal for the purpose of private study or research.

- You may not further distribute the material or use it for any profit-making activity or commercial gain

If the publication is distributed under the terms of Article $25 \mathrm{fa}$ of the Dutch Copyright Act, indicated by the "Taverne" license above, 


\title{
CAUSES OF LABOUR SUPPLY AND DEMAND MISMATCHES IN THE DUTCH BUILDING TRADES**
}

\author{
$B Y^{\prime \prime}$
}

\section{A. DE GRIP*}

\section{INTRODUCTION}

Since the end of the 1970's several studies have been published in which estimates are made of the development of frictions between supply and demand on the Dutch labour market by means of so-called UV analysis (e.g. Driehuis (1978), Kuipers and Buddenberg (1978), Heijke (1982), Van Ours (1982), Van den Berg (1982), De Koning (1982, 1984), Muysken, et al. (1982), Den Broeder et al. (1984, 1985) and De Nieubourg (1985)). Similar studies have been published on other countries' data (e.g. Gujarati (1972), Taylor (1972), Holden and Peel (1975) and Reid and Meltz (1979)). A different approach can be found in Nickell (1982).

One of the reasons for the attention various economists devote to labour market frictions is the noticeable increase of market imperfections starting in the mid-1960's (Driehuis (1978), Heijke et al. (1985)). Most of the studies mentioned refer to the labour market at macro-eonomic level. Some studies also attempt to explain the development of labour market frictions by means of a number of exogeneous proxy variables. In a few cases these explanatory variables are explicitly placed in a search-theoretical framework, in which an increase of labour market friction is postulated as a result of increased incentives for extended job search.

Hardly any research has been published in which labour market imperfections at industry level are explained. One of the reasons for this is probably the difficulty to define an industry's labour market with the available statistical data. One of the lew labour market friction analyses at industry level is the study of Heijke (1983) in which the dewelopment of imperfections on the Dutch building-trade labour market has been estimated for the period 1955-1981. Heije finds that labour market friction as a percentage of employment in this

* Research Centre for Education and Labour Market., Department of Economics, University of Limburg. Maastricht. The Netherlands. At the monent of writing this paper the author was working at the Department of Economics. Free University, Amsterdam, The Netherlands.

* The author would like to thank Prolessor J.A.M. Heijke, dr. N. van Hulsi. Proressor J.G. Knol. Prolessor J.J.M. Theeuwes and Professor A.J. Vermaat for their helpful comments on an earlier draft of this paper and G.A. van Pruissen for his assistance in computer work. 
industry is relatively high."

This high frictional unemployment makes the building-trade labour market an interesting subject for a UV analysis at industry level. Moreover, compared with other industries, the construction industry shows a relatively high overlap between the industry and the relevant occupations. As the extent to which labour market frictions can be found depends on the registration of unemployment and vacancies, probably part of the relatively high labour-market imperfection recorded in the building trades is a result of high registration of both unemployed workers and vacancies in this industry. This increases the reliability of a UV analysis for this industry, compared with macro-economic UV analysis. An analysis of the causes of labour market imperfections at industry level also has the advantage that the explanatory variables may have less of a proxy character than usual in macro-economic research. All this makes the buildingtrade labour market very suitable for analysing causes of labour market imperfections.

In this paper the significance of some hypotheses on possible causes of increasing or decreasing labour market frictions will be tested on labour market data of the Dutch building trade for the period 1955-1981. This period has been chosen on the basis of the availability of annual data for most of the variables used in the analysis. Moreover such a relatively long time-series has the advantage that it may enable us to explain the rise of labour market frictions since the middle of the 1960's.

In contrast with most other UV research on causes of labour market friction. which, after Holt (1970) and Gujarati (1972), explicitly or implicitly focussing on changing incentives for job search, occurs within a job-search framework, this paper defines the friction problem within a human-capital 'matching' framework, focussing primarily on skill differences in the composition of labour market supply and demand.

The next section (2) deals with the two lines of research in UV analysis that enable us to test the significance of possible causes of labour market imperfections, what we will call. the 'direct' and 'indirect' method. Section 3 describes the possible 'imperfect matching' hypotheses tested in this paper. Section 4 reports on the empirical results using OLS regressions. The results show that the imperfect matching framework enables us to explain labour market frictions to some extent. In section 5 a typically job-search explanatory variable - the wage-benefit ratio - will be added to our analysis. This however does not improve the estimation results obtained from the imperfect matching model. The concluding section 6 sums up the main results and policy implications of this paper. 


\section{DIRECT AND INDIRECT TESTUNG METHOD}

Until now two different lines of research hawe been followed in UV analysis, attempting to explain shifts of the UV relation. The method most commonly used, which we will call the direct method, refers to testing the UV relation:

$$
\ln (u)=\alpha+\sum_{i=1}^{n} \beta_{i} \ln \left(X_{i}\right)+\gamma \ln (v)
$$

where: $u=$ unemployment as a percentage of the labour force or working population; $v=$ wacancies as a percentage of the labour force or working population; $X_{i}=$ explanatory variables, by which shifts of the UV relation can be explained; $\alpha, \beta_{i}, \gamma=$ parameters.

Research following this direct method has been done by e.g. Reid and Meltz (1979) and De Neubourg (1985).

In other studies, research into the causes of labour market frictions has been split into two successive steps (Den Broeder et al. 1984, 1985). Therefore we call this the indirect method. First, annual friction unemployment is calculated by means of a simple UV relation or employment function, in which the actual wallues of $w$ and $v$ - or labour market supply and demand - are filled in. The second step in this indirect method refers to OLS estimates of equations in which the calculated friction unemployment is the dependent variable. Heijke (1983) follows this procedure in his building-trade labour market study. First, he calculates the annual friction unemployment percentage by means of the CES employment relation ${ }^{2}$ (Heijke, 1983, p. 7):

$$
E=\left(S^{-1} f+D^{-f}\right)^{-1 / f} \quad(f>0)
$$

where $E=$ employment; $S=$ supply of labour $(S=E+U) ; D=$ demand for labour $(D=E+V)$. $U=$ unemployment; $V=$ vacancies; $f=$ friction parameter.

For each year labour market friction as a percentage of the working population $(u f)$, can be calculated as follows (Den Broeder et al. 1984, p. 10):

$$
u f^{\prime}=2^{1 / s}-1
$$

This concept of equilibrium frictional umemployment can be defined as the unemployment that would exist if, for a given value of realised employment, supply and demand on the labour market would be found equal': $S=D$ (Heijke et al. 1985).

Hypotheses on causes of labour market frictions can then be tested by means of OLS estimates of the following equation:

$$
\ln (u f)=\alpha+\sum_{i=1}^{n} \beta_{i} \ln \left(X_{i}\right)
$$

2. Heijk ot al, (1985) sums up the relevant theoretical demands this CES specification satisfies. 
This indirect method has the advantage that an employment relation can be used to calculate the development of frictional unemployment. This employment relation can be considered more satisfactory because it refers to a direct causal relation, which the UV relation does not, as $u$ and $v$ are only related to each other through total supply and demand of labour (Holden and Peel (1975), De Koning (1982), Heijke (1983)).

Moreover, calculation of the annual frictional unemployment by means of the actual values of $S$ and $D$, avoids the influence of stochastic disturbances in the friction parameter $(f)$ on the parameters estimated for the variables $\left(X_{i}\right)$ which attempt to explain the development of the labour market imperfections. On the other hand the indirect method has the disadvantage that the extent of frictional unemployed is calculated a priori by means of an untested specification of a theoretical relation. This paper will not dwell on this methodological battle. OLS estimates will be performed for both the direct and the indirect method.

\section{POSSIBLE CAUSES OF LABOUR MARKET FRICTIONS}

As Holt (1970) already set out, labour market frictions can be explained from two different viewpoints: on the one hand search behaviour of unemployed workers and employers in the labour market and on the other hand the segmentation of the labour market in submarkets. It is striking that most studies of possible causes of friction unemployment usually define the analysis in a search-theoretical framework, with an extension into the geographical dimension of job-search behaviour in a few studies (Reid and Meltz (1979), Heijke (1982), Den Broeder et al. (1984, 1985), De Neubourg (1985)).

Hardly ever do explanatory variables explicitly refer to an imperfect matching framework, which does not concentrate on changes in labour market participants' search time, but focuses on causes of skill differences in the composition of labour supply and demand.

In this study labour market friction is analysed within a human-capital (or related institutionalist theory) framework, in which labour market frictions are explained from inadequate matching of heterogeneous labour supply and demand. This does not imply that frictional unemployment is merely an aggregate problem, in the sense of friction between markets. As the difference between frictions within markets and frictions between markets depends highly on the extent to which the labour market can be disaggregated, differences in the composition of labour supply and demand can also refer to frictions within the labour market segments that can statistically be identified, $e . g$. if such a mismatch refers to a simultaneous excess demand for experienced craftsmen and excess supply of inexperienced workers.

In this section seven hypotheses will be presented that may explain the development of building-trade labour market frictions. All hypotheses focus on processes that may lead to mismatches between the skill composition of labour supply and demand. 


\section{Relative demand for skilled craftsmen}

Changes in the schooling composition on the demand side of the labour market may cause frictions if labour supply cannot adjust adequately or fast enough. Such an inadequate supply response is most probable in the case of a demand shift from unskilled labour to the skilled building crafts, as the excess of unskilled labour supply will then mismatch excess demand for skilled labour. A suitable indicator for this skill-level aspect in the composition of labour demand is the share of repair and rebuilding in total building production. The distinction between repair and rebuilding on the one hand and new building on the other hand is relevant from a schooling point of view, as the often largescale nature of new building generally requires relatively much less all-round craftworkers than are needed for the usually small-scale repair and rebuilding. Howewer, the extent to which labour demand makes skilled craftsmen a bottlemeck on the building-trade labour market is also influenced by the competition between the construction industry and the other industries at the national labour market. Therefore we construct the following measure as an indicator of the influence of demand factors on the extent to which skilled craftsmen may be a relative bottleneck on the labour market:

$$
R D S C=\frac{R B}{T B} \cdot \frac{E B}{E T} \quad \text { (Data: CBS) }
$$

where: $R D S C=$ relative demand for skilled craftsmen;

$R B=$ nominal value of repair and rebuilding production;

$T B=$ nominal value of total building production;

$E B^{\prime}=$ employment in construction industry;

$E T=$ total national employment.

We are forced 10 use production data for the share of repair and rebuilding in building employment. Probably this value ratio does not exactly correspond to relative demand for labour, as repair and rebuilding is generally more labour intensive than new building. However, if we suppose that during the period considered there has been a constant ratio between the labour intensities of repair/rebuilding and new building, the above measure can be considered a suitable indicator of the development of the skill-level composition of the demand for labour in the construction trade. Moreover, we assume there can only be a shortage of skilled workers on the labour market.

As an increase of the above ratio may cause a (rising) relative shortage of skilled craftworkers and therefore can lead to an increase of labour market mismatch, we expect this explanatory variable to have a positive sign.

\section{Apprenticeships}

Labour supply can of course adjust to a relative increase of the demand for skilled craftsmen by training workers for the skilled building crafts. In the 
Dutch construction industry the greater part of this craft-schooling takes place in a 'dual' schooling system, the so-called "leerlingwezen." This dual-apprentices system offers young workers theoretical formal classroom training as well as a considerable amount of on-the-job training in their craft. As this dual schooling system involves costs for the firms employing apprentices, the apprenticeship possibilities for new labour market entrants often decrease during an economic downturn, when firms are less in need of (skilled) workers. In that situation young workers will not be considered for vacancies in the skilled construction crafts. This implies that unemployment which originates as cyclical, will be transformed into labour market frictions, as apprenticeship trainings then will fail to match the demand for skilled craftworkers with the supply of inadequately trained youths.

The indicator we take to test this hypothesis is the number of apprentices as a percentage of total employment:

$$
A P E=A P / E B \quad \text { (Data: CBS) }
$$

where: $A P=$ number of apprentices;

$A P E=i d e m$, as a percentage of total employment in the construction ind ustry.

As a fall in the number of apprentices may cause an increase of labour-market discrepancies, we expect this variable to have a negative sign.

\section{Reschooling}

The above dual-apprenticeship training only enables younger workers to acquire a training for the skilled building-crafts. However, in the Dutch construction industry 'mismatched" unemployed unskilled older workers also have a possibility to be trained for the skilled crafts. This (re)schooling possibility has already existed for a long time at the "Centra voor Vakopleidingen van Volwassenen' (CVV's). Schooling for various building crafts accounts for an important part of these CVV trainings.

As a matter of fact this (re)schooling possibility is a government labour-market instrument explicitly aimed at decreasing labour market frictions. Doubtlessly (re)schooling older workers will only occur if the greater part of the schooling costs is subsidized, as this (re)schooling is always less profitable than apprenticeship trainings for youths. First, firms will face higher opportunity costs when they invest in the human capital of older workers. Second, the period during which they can profit from their investment is shorter.

As a measure of the effect of reschooling older workers we take the number of workers that successfully completed schooling in the year of observation as a percentage of total employment in the construction industry.

$$
C V V P=C V V / E B
$$

(Data: Ministry of Social Affairs and Employment) 
where: $C V V=$ number of certified school-leavers CVV-building crafts;

$C W V P=i d e m$, as a percentage of total employment.

If an increase of the number of reschooled workers causes a significant decrease of labour market friction, we could judge this labour market instrument as effective. In that case the sign of this variable must be negative.

\section{Experience discrepancies}

Undoubtedly the schooling of workers also has an experience component. Older experienced workers may be expected to be considerably more productive than inexperienced young workers. Of course this does not imply that experienced workers are always more preferred than inexperienced ones. The relative attractiveness of experienced and inexperienced workers depends theoretically on the extent to which the age-wage differential covers the marginal productivity difference between both groups. The age/experience wage structure can be disturbed in two ways. On the one hand young workers' wages can be relatively too high, e.g. as a consequence of a relatively high minimum-wage level. On the other hand older workers can also be paid relatively too high wages, e.g. if their market power, trade unions or legal protection make their wages rigid at too high a level compared with wages young newcomers in the labour market earn.

As we have no information on marginal productivities relative to wages, we are forced to use a rather indirect indicator for the relative attractiveness of younger and older workers: the relation between vacancies open for younger workers and the total number of vacancies:

$$
E D=\frac{V 19}{V} \quad \text { (Data: CBS) }
$$

where: $E D=$ experience discrepancy;

$V / 9=$ number of vacancies open for workers younger than 19 years old;

$V=$ total number of vacancies.

If a decrease in the number of vacancies for youths coincides with an increase of labour market frictions, we assume that the relative overpay of inexperienced youths has been a cause of this friction. In that case this explanatory variable has a negative sign. If older workers' wages are relatively too high, we may expect a positive sign. However, this variable has much more of a proxy character than the other explanatory variables. Therefore we must be careful in interpreting the estimation results of this explanatory variable.

\section{Bumping-down processes}

In his job-competition theory, Thurow (1975) draws attention to the possibility that an excess of skilled workers will drive less skilled workers out of employment from their present job-level domain into lower job levels or into unemployment, if relative wages are rigid. Such a process can be characterized as 
a "bumping-down' process. Job-competition theory is often considered of special relevance to the allocation of new entrants in the labour market. However, as the construction industry can be considered a separate labour market segment, one would not expect school-leavers with a building-craft certificate to have to face competition of higher skilled school-leavers trained in another craft. But it is possible that within the building labour market bumping-down processes do occur.

First, experienced workers can drive school-leavers - with or without a certificate - out of employment. This aspect has as a matter of fact already been modelled above in the variable ED. Second, qualified school-leavers can drive out unqualified new entrants. Such a bumping-down process implies not only that unemployment is shifted onto the shoulders of unskilled school-leavers, but also that it takes more time before qualified school-leavers accept existing job openings that are less attractive than they expected before entering the labour market.

The extent to which a bumping-down process occurs depends on the one hand on the relative supply of qualified school-leavers and on the other hand on the 'absorption capacity' - the entrance possibilities - of the labour market. Both elements are represented in the following indicator:

$$
B D=\frac{Q T S-V 19}{E B}
$$

where: $B D=$ bumping-down indicator;

$Q T S=$ school-leavers qualified for the building crafts.

For this explanatory variable we expeci a positive sign, as an increase of the number of certified school-leavers in relation to the number of vacancies for younger workers may lead to an increase of the extent to which uncertified youths are driven out of employment in the building trades.

\section{Secondary labour market}

According to dual labour market theory the labour market consists of two different segments (e.g. Edwards, Gordon and Reich (1975)). A stable primary segment with skilled 'career' or "craft' jobs and an unstable secondary segment with unskilled 'dead-end' jobs. Secondary labour markets are characterized by high quit rates, as labour supply on these market segments is not tied to a certain occupational domain in the way primary workers are. Moreover, most secondary jobs are rather unstable and often lead to demotivated and dequalified workers, who develop bad working habits. Because of this "pathological instability' (Hall (1970)) of employment, secondary labour markets may lace large labour market frictions (see e.g. Doeringer and Piore (1971)). ${ }^{3}$ As craft markets 
can also have a relatively high intra-industry labour mobility, secondary labour markets can best be identified by a high inter-industry mobility (Alexander (1974)), because unskilled workers employed in dead-end jobs are easily inclined to search for jobs in other industries. However, entrance and exit of labour supply in and out of an industry strongly depends on the employment possibilities in the industry. In this way an important fall in employment in the building trade can also force craft workers to search for jobs in another industry. Therefore, a suitable measure for identifying the relative importance of secondary labour markets can only be derived if we correct the inter-sector mobility $(R E+F E+Q)$ for mutations in the sector"s employment $(\triangle L S)$. In Van Bergeijk and De Grip (1986) we developed such a corrected measure. This socalled 'contrarious mutation percentage' can be calculated by the following equation:

$$
C M P=\frac{R E+F E+Q-|\triangle L S|}{2 L S}
$$

where: $C M P=$ contrarious mutation percentage;

$R E$ = reentrance into building trade:

$F E$ = first entrance into building trade;

$Q \quad=$ quits out of building trade;

$L S$ = labour supply in the building trade.

As the data used refer to a period going from May in the previous year to May in the year of observation, it is advisable to average the annual data:

$$
S A M_{t}=1 / 2\left(C M P_{t}+C M P_{t-1}\right)
$$

where: $S A M=$ secondary labour market indicator.

Or course this $S A M$ indicator can only be considered as a proxy variable to the extent to which the building-trade labour market contains secondary segments. As an increase in the importance of such secondary segments may cause more labour market frictions, the expected sign of this explanatory variable must be positive.

\section{Long-term unemployment}

Long-term unemployment can create a 'hard core' of unemployed workers, who cannot compete for jobs any longer with those unemployed for only a short period. Such a process is often caused by the fact that long-term unemployment mostly implies al gradual dequalification of previously skilled workers. This dequalification process is reinforced by so-called "negative feedback processes" in which unemployed workers get demotivated and lose their work discipline. Moreover, the mere possibility of such a dequalification or demotivation process often implies stigmatization of the long-term unemployed, which makes it very difficult for every long-term unemployed worker to com- 
pete for a job. The existence of a "hard core" of unemployed workers can be an important cause of the persistence of labour market frictions even if the economy recovers again.

The indicator we use for this possible cause of labour market frictions is the number of workers that is unemployed for six months or longer at the end of November of the previous year as a percentage of total employment:

$$
\left.U L P_{t-1}=\left(\frac{U L}{E B}\right)_{t-1} \quad \text { (Data: } \mathrm{CBS}\right)
$$

where: $U L=$ number of long-term unemployed ( $>6$ months);

$U L P=i d e m$ as a percentage of total employment in construction industry. ${ }^{4}$

The one-year lag in this wariable refers to both the gradual process of dequalification and demotivation and the way in which long-term unemployment may prolong labour market frictions. As an increase of this hard core unemployment can imply higher labour market frictions in the next period, we have to expect a positive sign for this variable.

\section{RESULTS OF TIME-SERIES ANALYSES}

The hypothesis formulated in section 2 will be tested by both methods used in UV analysis literature: the direct testing method where $u$ is the dependent variable and the indirect method where $u f$ must be explained. These $u f$ figures, calculated by means of equations (2) and (3), are obtained from Heijke (1983). Both variables are expressed as a percentage of total employment in the construction industry, in the same way as the explanatory variables.

Table 1 shows the estimation results of our model for the period 1955-1981, for both testing methods. The first two equations from Table 1 include all explanatory varables for which data are available for the entire testing period. In the direct method UV equation (1) all variables have the expected sign, but the parameters of the $B D, C V V P$ and $U L P$ variable do not significantly differ from zero. In the indirect method equation (2) only the ULP variable is insignificant, although the CVVP variable also is only significant at a $95 \%$ confidence interval. Also the $D W$ statistic for first-order autocorrelation of this equation is satisfactory.

The third and fourth equation of Table $\mathbb{\|}$ show the estimation results of the equations without the $U L P$ variable. In the third equation now on $\| y$ the $C V V P$ variable parameter is insignificant and the $B D$ variable is only significant at the $90 \%$ level. The $D W$ statistic is still in the uncertain region. The fourth equation,

4 It is striking that the term long-term unemployment has been intlating recently. Sometimes the term only refers to unemployment spells of more than 2 or 3 years. We however prefer to use the $>6$ months criterium, which was standiand up to the $1970 \mathrm{~s}$ s. 


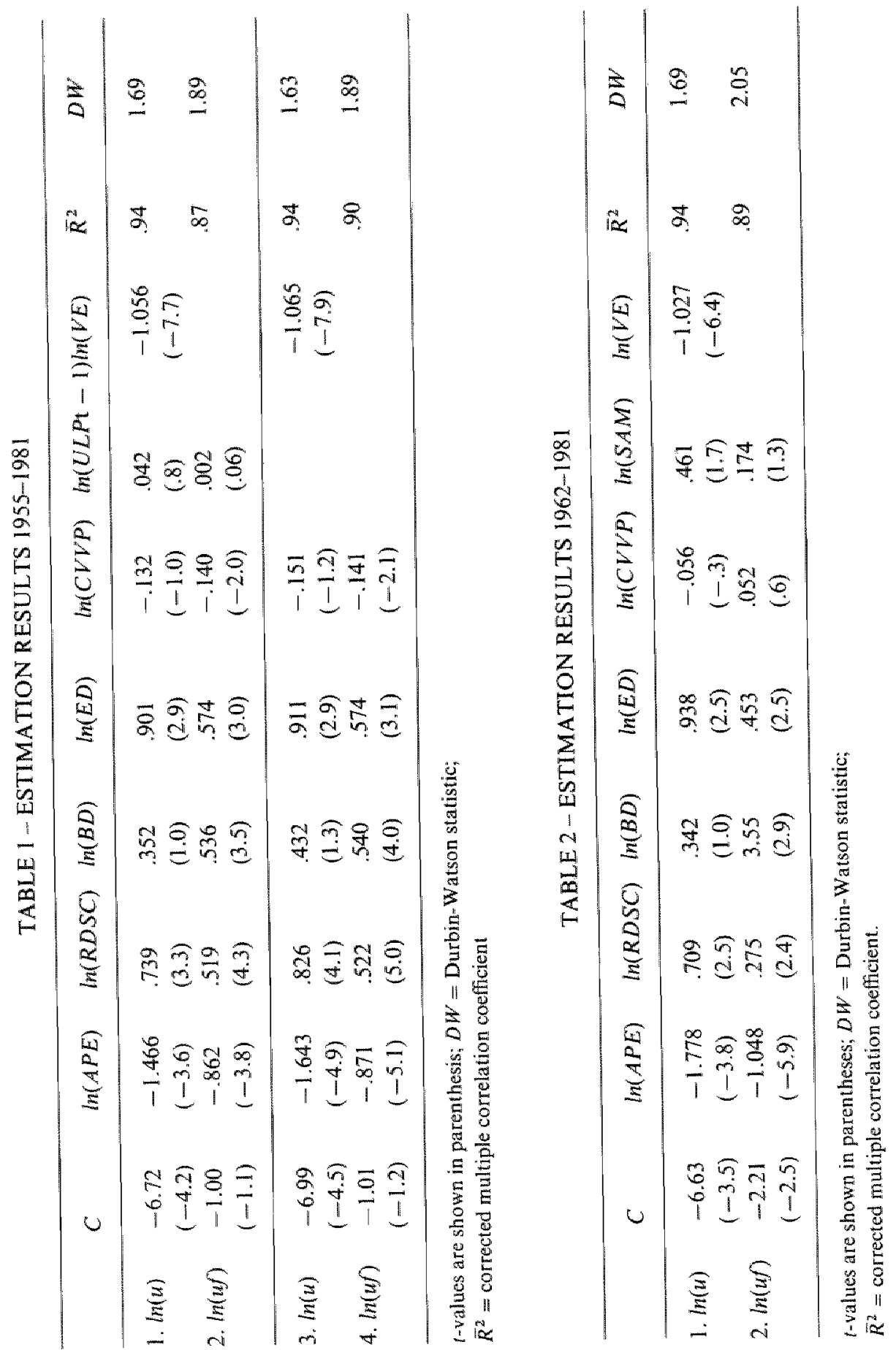


however, now shows good results for all explanatory variables. As excluding the $B D$ and/or the CVVP variable from equation 3 does not improve estimation results, we may regard the latter two equations of Table $\mathbb{L}$ as the best results according to both estimation methods.

The hypotheses explaining significant causes of shifts in labour market frictions in the Dutch construction industry and according to both testing methods are:

- relative demand for skilled craftsmen $(R D S C)$;

- number of apprentices ( $A P E)$

- in relation to their relative productivity - compared with young workers too highly paid older workers $(E D)$.

Apart from these three variables, also bumping down processes seem to have some explanatory value for labour market friction, although according to the direct method estimates this variable is only significant at the $90 \%$ level. The same applies for the reschooling of older workers at the CVV"s. However, the parameter of this explanatory variable only differs significantly from zero in the indirect method estimates.

In both testing methods the $S A M$ variable has the expected sign. However, in both cases the coefficient differs significantly from zero at a $90 \%$ confidence level only. Moreover, now the CVVP variable also appears to be insignificant in the indirect method estimates. For the direct method equation the $D W$ statistic lies in the uncertain region; for the indirect method equation the statistic is satisfactory.

The $\bar{R}^{2}$ statistics show that including the $S A M$ variable does not improve explanatory value of the equations compared with equations 3 and 4 of Table 1 , estimated over the same sample period. As excluding the variables $C V V P$ and/or $B D$ from the equations does not improve estimation resulls, we do not present the results of these estimates here.

What we have not yet discussed ate the differences between the coefficients in both testing methods. The main reason for these differences is of course the fact that in the direct method equation not labour market frictions but total unemployment is the dependent variable. To find comparable parameters we have to transform equation (1) as follows:"

$$
\begin{gathered}
\ln (u)=\alpha+\sum_{i=1}^{n} \beta_{i} n\left(X_{i}\right)+\gamma \ln (v) \\
u f=u-v \\
\ln (u f)=\alpha+\sum_{i=1}^{n} \beta_{i} \ln \left(X_{i}\right)+\gamma \ln (u f) \\
\ln (u f)-\gamma \ln (u f)=\alpha+\sum_{i=1}^{n} \beta_{i} \ln \left(X_{i}\right)
\end{gathered}
$$


TABLE 3-RECALCULATED PARAMETERS

\begin{tabular}{|c|c|c|c|c|c|c|c|}
\hline $1955-81$ & $C$ & $\ln (A P E)$ & $\ln (R D S C)$ & $\ln (B D)$ & $\ln (E D)$ & $\ln (C V V)$ & $\ln (S A M)$ \\
\hline 1. $\ln (u n)$ & -1.32 & -.795 & .400 & .209 & .441 & -.073 & \\
\hline $\begin{array}{l}\text { 2. } \ln (u)^{4 / 11} \\
.962-81\end{array}$ & -1.01 & -.871 & .522 & .540 & .574 & -.141 & \\
\hline 3. $\ln (4)$ & -3.27 & -.877 & .349 & .169 & .463 & -.028 & .227 \\
\hline 4. $\ln (u f)^{n+1}$ & -2.21 & -1.048 & .275 & .355 & .453 & .052 & .174 \\
\hline
\end{tabular}

$(w /)^{u E}=$ equilibrium friction resulting from $U V$ relation (see eq. 13).

$$
\ln (u f)=\frac{\alpha}{1-\gamma}+\sum_{i=1}^{n} \frac{\beta_{i}}{1-\gamma} \ln \left(X_{i}\right)
$$

Table 3 shows the result from a recalculation of the parameters of the third equation of Table 1 and the first equation of Table 2, according to equation (13), compared with the corresponding indirect method estimates.

The in-all-equations-significant parameters $R D S C, A P E$ and $E D$ now appear to be more or less comparable. From this can be concluded that the estimation results of the UV model do not differ much from the results of a CES employment rellation. One of the reasons for the remaining differences is of course the different specification of both functions. Moreover, the differences may be due to the fact that in the indirect method the implicit coefficient of $V$ is not an estimation result, but annually calculated by filling in the actual values of $S$ and $D$ in equation (2). This avoids the influence of stochastic disturbances in the friction parameter on the estimation results of the other variables.

As most of the explanatory variables only claim to have a proxy character, we cannot possibly interpret the coefficients too strictly. Therefore the main purpose of our analysis can only be determining whether the signs of the explanatory variables correspond with the hypotheses tested. However, the parameter value of the $A P E$ variable is remarkably high. To some extent we can attribute this to the fact that, although the greater part of craft training in the building trades occurs within the formal apprenticeship trainings, there also are several other formal trainings or jobs with considerable on-the-job training. In as much as the APE variable is correlated with the development of these alternative trainings, it is possible that the $A P E$ variable also represents the infuences of the alternative trainings on labour supply adjustment to labour market frictions.

Of course it is interesting to determine which causes were responsible for the rise of frictional unemployment in the two periods in which the increase was most severe: 1964-1967 and 1969-1976 (especially 1972 and 1974). We reler hereby to the results of the third and fourth equation of Table 1 . The mid- 
1960's increase in frictional unemployment appears to be caused by several explanatory variables: $A P E, E D, C V V$ and $B D$. However, the main causes of the $1969-1976$ increase were the $A P E$ and $R D S C$ variables and to a smaller extent the $B D$ variable. Again the lack of apprenticeship trainings appeared to play a crucial role in generating frictional unemployment. Especially during the years 1973-1977 the rising relative demand for skilled craftsmen as a result of the increasing importance of repair and rebuilding contributed considerably to the growth of frictional unemployment. During this period the $E D$ variable had a negative influence on the level of frictional unemployment. This would mean that the increase of relative youth wages during this period offset the relative owerpay of older workers due to the wage boom in the 1960's. In the period 1976-1981 we see a levelling off of the increase in frictional unemployment. During this period the increase of apprenticeship (APE) and reschooling ( $C V V P$ ) contributed most to stopping the growth of frictional unemployment.

\section{ADDITIONAL CAUSES}

It may be interesting to combine the matching framework presented above with a "traditional" job search variable. Therefore we also tested the significance of the well-known job-search hypothesis, according to which an increase of the relative height of the average social benefits compared with average netwages will result in a lengthening of search time of the unemployed workers. The variable we use is the so-called wage-benefit ratio $(W B R)$ :

$$
W B R=w / u b
$$

where: $w=$ average net wage; $u b=$ average net unemployment benefit.

This variable must therefore have a negative sign on theoretical grounds. As an indicator we use the macro-economic data developed by Den Broeder at $a$. (1985), assuming that the development of this macro-economic wage-benefit ratio parallels the development of the wage-benefit ratio in the construction trade. However, these data do not go back as far as 1955. Table 4 shows the best results of OLS estimates of equations with the additional WBR variable.

The WBR variable has the expected sign in both the direct and indirect lesting method, but it only appears significant at a $90 \%$ level in the second equation of Table 4. In the direct method the variable does not have any additional explanatory value. Moreover, the addition of this job-search theory variable only has a positive influence on the $\bar{R}^{2}$ statistic of the indirect method estimates (compared with Table 2).

\section{CONCLUSIONS}

In contrast with most other research on causes of labour market friction, this paper reports on research focussing on hypotheses from a human-capital - or 


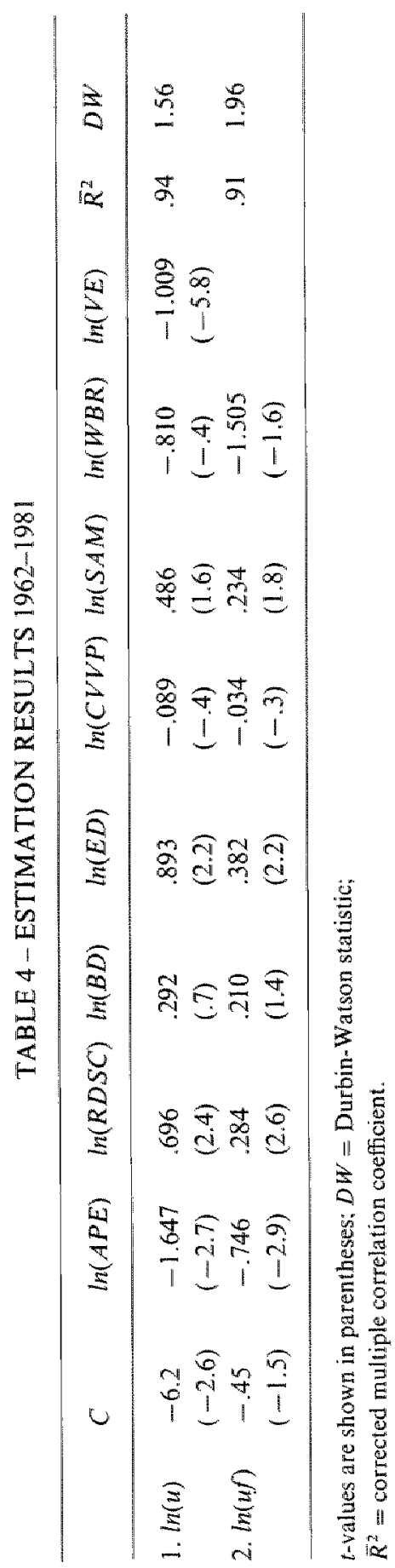


related institutionalist theory - "matching' framework. Some of these imperfect matching hypotheses appear to be able to explain quite well the development of labour market frictions in the Dutch construction industry in the period considered. According to both the direct and the indirect testing method, several variables representing these hypotheses can be seen as significant causes of labour market frictions in this industry. These causes are: the development of the skill-composition of labour demand $(R D S C)$, the apprenticeship possibilities $(A P E)$ and the too high relative wages of older workers $(E D)$. The apprenticeship training appeared to be responsible for both the mid-1960's and the 1969 1976 increase of frictional unemployment. The relative overpay of older workers was one of the causes of the mid-1960's increase. The rise of the relative demand for skilled craftsmen led to increasing frictional unemployment in the 1970 's, due to the growing importance of repair and rebuilding in total building production.

The relevance of the development of apprenticeship possibilities confirms the importance both unions and employers in construction industry attach to apprenticeship training at the moment. Within the building trade, the exchange in the skill composition of labour demand as a result of the increased importance of repair and rebuilding is also broadly held responsible for the existing frictional unemployment. The fact that relative wages of older workers would be too high compared with youths' wages, however, is not heard publicly. As the variable used to test this hypothesis has much more of a proxy character than the two other always significant explanatory variables, we have to be careful in interpreting the significance of the experience-discrepancy variable.

Moreover there is some indication of bumping-down processes by which certified school-leavers are crowding out school-leavers without a building-trade school certificate. However, the results of this variable are not very stable. The same can be said of the hypothesis which states that the existence of a secondary labour market segment of unskilled workers also implies an increase of labour market frictions. Moreover, estimation results do indicate a weakly significant negative effect of the reschooling of unemployed adult workers on the level of friction unemployment in the construction industry. The long-term unemployment hypothesis does not contribute significantly to the explanation of labour-market imperfections in the construction industry in the period considered.

An important policy implication of this research undoubtedly is that it is highly important to stimulate an increase of the apprenticeship possibilities in the construction industry, as labour supply adjustment by means of apprenticeship-training appears to be a principal cause of labour market imperfections in the building trades. The research presented in this paper also indicates that it is recommendable to increase the skill level of the workers in the building trade. This will probably solve the skill mismatch on the labour market caused by the transition from the often large-scale new building projects to repair and rebuilding projects, which can be seen as a structural development, requiring 
relatively more skilled craftworkers. Furthermore, a relative decrease of the number of unskilled workers may induce a decrease of parts of the building trade labour market that can be characterized as secondary labour markets in which - usually unskilled - workers frequently face periods of unemployment.

Although the reschooling variable only appeared to have a weakly significant effect on frictional unemployment in the construction industry, we may carefulIy conclude that the reschooling of adult workers in the CVV's probably has some effect in fighting frictional unemployment.

The significant positive sign of the experience-discrepancies variable is also important from a policy point of view, as it rejects the supposition often heard nowadays that a decrease of relative youth wages will improve the functioning of the labour market. For the construction industry labour market this does not appear to hold true. However, as has been said before, the rather indirect proxy character of the explanatory variable representing the experience-discrepancy hypothesis means that we have to be careful in interpreting the significance of this variable.

The above shows that an imperfect matching framework offers good possibilities to explain labour market imperfections in UV or employment relations analyses. Adding a well-kmown job-search theory variable, the wage-benefit ratio, did not improve remarkably the estimation results of the equations.

\section{REFERENCES}

Alexander. A.J., "Income, Experience and Internal Labour Markets," Quarterly Journal of Economics. 1974, pp. $63-85$.

Berg, D.J. van den, "Specification and Estimation of the Unemployment-Vacancy Curve in the Period 1956-1979;' De Economist, 1982, pp. 397-419.

Bergeijk, K. vatn, and A. de Grip (1986), 'Bestaan en ontwikkeling wan interne arbeidsmarkten in Nederland," Socinal Maandblad Arbeid, 1986, pp. 437-45I.

Broeder, G. den, J.A.M. Heijke, and J. de Koning, "Friction Between Supply and Demand on the Netherlands Labour Market.' Foundations of Empirical Economic Research 1984/2, Netherlands Economic Institute. Division of Labour-Market Research, Rotterdam, 1984.

Broeder, G. den, J.A.M. Heijke, and J. de Koning. 'Een vastgelopen arbeidsmarkt; kan het ook anders?", Ecomomisch Statistische Berichten, 1985, pp. 772-776, 779.

Brown, A.J., 'UV Analysis,' in: G.D.N. Warwich (ed.), The Concept and Measurement of In wolumsary Unerwployment, London, 1976, pp. 134-145.

Doeringer. P.B., and M.J. Piore, 'Tnternal Labor Market and Manpower Analysis,' Lexington, Mass, 1971 .

Driehuis, W.. 'Labour Market Imbalances and Structual Uemployment," Kyklos. 1978, pp. 638661

Edwards, R.C.. M. Reich, and D.M. Gordon, 'Labor Market Segmentation,' Lexington, Mass.. 1975.

Evans, G.J., A Note on Trends in the Relationship Between Unemployment and Unfilled Vacancies," Economic Journal, 1975, pp. 135-139.

Gujarati. D., "The Behaviour of Unemployment and Unfilled Vacancies: Great Britain 1958- 
1971, Economic Jownal. 1972, pp. 195-204.

Hall, R.E., "Why is the Unemployment Rate So High at Full Employment?" Brooking Papers, 1970 , pp. 369-402.

Heijke. J.A.M., "Arbeidsallocatie en loonstructumr," in: J.C. van Ours, C. Molenaar and J.A.M. Heijke, De wisselwerking tussen schaarsteverhoudingen in hell arbeidsbestel. WRR, V-20, "s-Gravenhage, 1982 , pp. $207-302$.

Heije. J.A.M., "The Performance of the Wage Mectranism in the Building "Trade," Foundation of Empirical Economic Research, 1983/9, Netherlands Economic Institute, Diwision of LabourMarket Research, Rotterdam, Oct. 1983.

Heijke, J.A.M., J. de Koning, R.J.M. Maas, and G. den Broeder, "A Model of the Durch Labour Market (AMO-K), De Economist, 1985, pp, 484-526.

Holden, Ka., and D.A. Peel. "The Determinations of Unemplloyment and the "UV" Relationship," Applied Economics. 1975, pp. 251-255.

Holt, Ch.C. "How Can the Phillips Curwe Be Moved to Reduce Both Intlation and Unemployment?, in: E.S. Phelps et al. Mircoeconomic Foundations of Employment and Inflation Theory, London and Basingstoke, 1970, pp. $224 \cdots 256$.

Koning, $J$, de, 'Interpretation, Volume and Causes of the Shifts in the UV-Relation in the Netherlands in the Period 1947-1980," Foumdations of Empirical Economic Research, 1982/4, Netherlands Economic Institute, Rotterdam, 1982.

Kuipers, S.K., and F.H. Buddenberg, 'Unemployment on Account of Market limperfection in the Netherlands since the Second World War," De Economist, 1978, pp. 390 412 .

Muysken, J., Chr. de Neubourg and H. van der Burg (1982), 'Regional and Oceupational Labour Market Imperfections, the Netherlands, 1955-1980,' Inst. of Ecom. Research, Faculty of Economics, University of Groningen, Research Memorandum, nr. 105, Aug. 1982.

Nickell, S.J., 'The Determinants of Equilibrium Unemployment in Great Britain,' Economic Journal, 1982 , pp. 555-575.

Neubourg, Chr. de, "The Origin and Insignificance of Labour Market Imperfection in the Netherlands: Another Note on the Specification of the UV curve 1955-1980, De Economist, 1985, pp. $64-77$.

Ours, J.C. van, 'De wisselwerking tussen schaarstewerhoudingen en beloningsstructuur; een empirische analyse van drie bedrijfstakken.' in: C.J. van Ours, C. Molenatr, and J.A.M. Heijke, De wisselwerking tussen schaarsteverhoudingen in het arberabestel, WWR, W-26. "S-Gravenhage. 1982, pp. $11-89$.

Reid, F., N.M. Meltz, "Causes of Shifts in the Unemployment-Vacancy Relationship: An Empirical Analysis for Canada., Review of Economicis and Statistics, 1979, pp. 470-475.

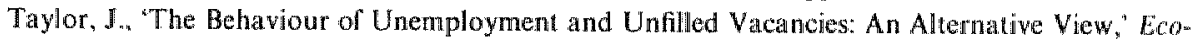
nomic Jownal, 1972 , pp. 1352-1365.

\section{Summary}

\section{CAUSES OF LABOUR SUPPLY AND DEMAND MISMATCHES IN THE DUTCH BUILDING TRADLS}

In this paper the sigmificance of some hypotheses on possible causes of labour supply and demand mismatches is tested on data of the Dutch building trades by means of a UW analysis. In contrast with most other UV research this study does not refer to a search-theoretical fromework, but fo- 
cuses on skill differences between labour supply and demand. Three significant causes of labour market frictions appear to be: the development of the skill composition of labour demand, the apprenticeship possibilities and the relatively high wages of older workers. Some other hypotheses show weakly significant results: bumping-down processes, reschooling of unemployed older workers and the development of secondary labour market segments. 